\title{
Changes in The Mythic and Pragmatic Areas of The Bali Aga Period Dwelling Building (8th Century) in Sidatapa Village Bali Againts Modernity
}

\author{
Imam Santosa $^{1^{*}}$ Ida Ayu Dyah Maharani ${ }^{2 *}$ Carina Tjandradipura ${ }^{3}$ \\ 1. Faculty of Art and Designt, Bandung Institute of Technology, PO Box 40132 Ganesa 10, Bandung, West \\ Java, Indonesia. \\ 2. Faculty of Fine Arts and Design, Institute, Nusa Indah, Denpasar, Bali Indonesia 80235 \\ 3. Faculty of Art and Designt, Bandung Institute of Technology, PO Box 40132 Ganesa 10, Bandung, West \\ Java, Indonesia. \\ * E-mail of the corresponding author: imamdotsantosa@gmail.com
}

\begin{abstract}
Architecture and culture are two subtle concepts that represent community identification. By understanding the local architecture, the level of civilization in the region will be known. The dwelling building of Sidatapa Village is a vernacular architecture, which was built for the first time in the 8th century as a take cover and shelter. The formation was initially influenced by myths related to belief. Furthermore, in its development, the shape of the building was transformed from basic symbols into a symbol of expression due to the shift in its meaning and function. This research was conducted to understand the process of transforming a dwelling building structure from a basic symbol to an expression symbol in an area that is very close to beliefs and traditions, through ethnographic research. The findings show change in the form of dwelling buildings is not only caused by changes in the natural environment, but also changes in housing needs and modernization processes, but leave its religious nature.
\end{abstract}

Keywords: Bali Aga, Dwelling buildings, Sidatapa Village, Vernacular Architecture

DOI: $10.7176 / \mathrm{ADS} / 91-05$

Publication date:March $31^{\text {st }} 2021$

\section{Introduction}

Sidatapa village a village of Bali Aga period in Banjar District, Buleleng, and has a distance of about $24 \mathrm{~km}$ from Singaraja city or $105 \mathrm{~km}$ from Denpasar city. Appearance of buildings in the Sidatapa village has similarities with other Bali Aga buildings around Sidatapa village, like in the Cempaga, Tigawasa and Pedawa village. The dwelling buildings are located in the site of the village with linear pattern dwelling yard arrangement, putting luan as main orientation of the village, every of the dwelling yard which consists of a mass of the dwelling building; has several similarities that can be found in those four villages. What distinguishes them is that in the Sidatapa village there is a myth that gives effect to the form of its dwelling space. According to the elders' tale, the dwelling building in Sidatapa village initially did not have a pelinggih in a room in the building as it is now (pelinggih always outside of the building that is in luan dwelling yard).

In ancient times there were myths in Sidatapa village about giants who were subordinates of Maya Danawa (the last descendant of the Warmadewa Dynasty in the Bali Aga era, around the 13th century) who were not happy to see the Sidatapa citizen worshiping God because the King claimed to be God. If there is villagers there who worshiped God then their pelinggih will be destroyed, even the worshipers would be tortured until killed. This causes the villagers to be afraid to make pelinggih outside their dwelling buildings. However, encouraged by their love for God then made the face of the building opposing the road to cover their pelinggih that is near the road. The pelinggih becomes protected and becomes part of the inner space in the dwelling building, and is not visible from the outside. Since then citizen of Sidatapa village was able to carry out the ritual worship to God and there is no further disturbance of the Maya Danawa's giant.

But now, with the inclusion of modernity values, the dwelling buildings in Sidatapa village (and other Bali Aga villages) have changed, along with changes in the surrounding natural environment, the demand for efficiency plays a role in determining the form of dwelling space. 


\section{Research Method}

This research collects data in a real environment, where researchers themselves functioned as a means of primary research. The research focus is the process or activity, not just the results of the process or activity. The data collected is verbal (non-numeric), therefore this research uses ethnographic methods. The research procedure is qualitative to describe, analyse, and interpret elements of a cultural group such as a pattern of behaviour, beliefs and languages that evolve over time. Observations were made in the four Bali Aga villages in Banjar District, Buleleng Regency, namely Sidatapa, Cempaga, Tigawasa and Pedawa Villages. Of the four villages, Sidatapa village is selected as the location of the study because there is a dwelling that uses the values of the Bali Aga time and dwelling that has been modernized. Next two buildings were selected, which still had the values of Bali Aga and two buildings that had adapted to the values of modernity.

\section{Literature Review}

\subsection{Vernacular Dwelling Space}

Vernacular architecture is basically humanist thinking, because it is a process as well as a product of creative products, taste, intention and human work as an effort to give meaning to the environment. Vernacular architecture is progressive and contextual, because it develops to answer the challenges of the environment and its current conditions. In Bali Aga era, dwelling building is made to meet the needs of dwelling with modest beliefs (in accordance to the opinions of Heidegger (Siregar 2008) which that building is the place to prove the existence of humans as occupants or users of dwelling space in real (being)).

The concept of 'dwelling' at the beginning in Sidatapa village is also to reminisce Rapoport (1969) opinion, that when humans started settling down, the dwelling building is self-built with technology, simple material and with the local way as an attempt to fulfil human needs to take cover and shelter from the surrounding environment. Its construction technique is developed locally by the community and have been tested for years. The building principle that is carried out by the community in establishing dwelling buildings is an effort to get closer to the nature surrounding it. The use of building materials obtained from the surrounding environment makes the form of the building harmoniously integrated with nature. Conformity between one dwelling buildings with the others, creating a taste of settlement in the Sidatapa village familiar in human scale. According to Rudofsky (1964) opinion the use of materials, simple technology, the color, the shape of the building, the arrangement of inner and outer space, as well as the end of the completion gave complete form that has an element of originality in the dwelling space and can meet the functional needs of the occupants. Jackson (Gartiwa 2011) stated that through traditions carried on for generations and lengthy trial and error efforts, dwelling buildings are timeless because they have long sustainability, even their existence can still be found in the present.

As a physical product, the dwelling culture in Sidatapa Village is not only a physical artefact, but also an implementation of community cultural concepts such as: meaning, values and norms and ethics that are adhered to generation to generation. Therefore, the dwelling space of Sidatapa Village is considered as an implementation of the culture of the inhabitants. As Oliver (2003) stated:

All houses are dwellings but all dwellings are not houses...Dwelling is both process and artefact, it is the experience of living at a specific location and it is the physical expression of doing so...dwelling is more than the structure, as the soul is more than the body that envelops it.

The results of field observations show that in the present time there is still an effort to maintain the old concept which is a tradition from the era, even though it has undergone adaptation, modification and shift in function. The changes are in the form of differences in orientation, interior layout, use of building materials and dimensional systems.

\subsection{Balinese Traditional Dwelling Space}

Balinese architecture can be categorized according to its era (Gelebet 1985) becomes Bali Mula Architecture (before the 8th century), Ancient Balinese Architecture or Bali Aga (8th to 13th centuries), Bali Arya or Bali Madya Architecture (14th to 18th century), Balinese Colonial Architecture (19th century) and Modern Balinese Architecture (20th century to the present). The concepts in Traditional Balinese Architecture that are best known are the concepts of Bali Madya Architecture (after the influx of Majapahit influences into Bali in the 14th century), because this period is considered the golden age of Balinese Architecture. These architectural concepts have been passed down from one generation of Balinese people to the next generation by means of writing that 
was well known at the time. The rules on how to build those mentioned in Asta Kosali and Asta Bumi, can be found in several lontar (Remawa 2015). Some of these concepts are mainly used by dwelling spaces scattered in the low-lying areas of the island of Bali. Starting from this era, we already know the existence of undagi clearly.

In the development of Balinese dwelling spaces until today, a collection of several buildings from previous era grown in each Balinese people environment which has different patterns of belief and culture, spirit of the era, technology and materials and certain social and economic. The manifestation of Balinese dwelling space is diverse that can be lifted from the unanimity of desa-kala-patra. Through this diversity, we can still see some of the same basis (Remawa et al. 2006), such as:

This section relates to the data output stage. In order to labour redundancy besides negating the adverse effects of turnover and absenteeism, WOZIP is meant to estimate the number of workers for a production period based on the utilisation, disturbance, and idling rates acquired from the past period $t-1$ by the Equations (1) to (3). Exponential smoothing, a common forecasting technique in operations management, is used to find the $U_{t}, \delta_{t}$, and $\chi_{t}$ rates for the coming period. The general formula for exponential smoothing:

a. The traditional Balinese dwelling space is a microcosmos of the picture of the universe which is considered to be its macro cosmos.

b. The traditional Balinese dwelling space is a place to form and place individuals individually or in groups, in harmony with the universe as a whole, starting from the manners of putting oneself in their environment.

c. The traditional Balinese dwelling space is a picture of an understanding of nature made based on its analogy, it is also a translation of the traditional life principles that gives a picture of the totality of individual life and communities as a whole.

d. If the dwelling space is associated with beauty, the configuration of forms and shapes created is functional and not fictitious. The beauty emerge from the pure understanding is in accordance with religious norms, rituals of nature, tradition, procedure and processes to make it happen.

e. The traditional Balinese dwelling space has the ability to acculturate with outside cultures without losing its identity.

The Balinese people see the earth as a life. For them the mountain is considered a sacred place full of tranquillity, the plain of settlements as a place of activity of human life, the sea as a place of final disposal and decomposition from all the remains that is on earth. Traditional Balinese buildings, structurally created by the division of the roof as heads, pillar and wall as a body, as well as the floor foundation or bebaturan as legs. The orientation of the building trusts the mountain as a luan area (the main part) and the sea as a teben area (a vile part). Use of materials, selection of shapes and placement are governed by the guidelines for the construction of traditional Balinese dwelling space is an alignment attempt with the natural environment.

The location of the mountain in the middle of Bali island causes the orientation of the luan and teben of the people on the Bali island to reverse with what is believed by people who live in southern Bali (like mirrors). This belief develops in the principle of Sanga Mandala (division of the area into nine parts). Sanga mandala has an initial form of tapak dara (similar to the plus sign + ), with kaja and kangin considered as the main area. Kaja, is a direction considered to be related to the direction of the location of the mountain as luan. Kangin, is a direction that is considered to be related to the direction of sunrise. Area considered to be of utama ning utama value are kaja kangin, which is between kaja and kangin, in which both directions are considered to have primary value. On the contrary, opposite the utama ning utama valued area is the nista ning nista area which is located in the kelod kauh, located between the kelod which is considered to be the direction of teben with the kauh which is the direction of sunset which marks the end of a day.

The Balinese believe that outside themselves there are certain forces as natural power which can influence themselves. They believe that there is an owner on earth. Good manners do well among fellow human beings on earth and among people against forces outside himself. The process of building construction is carried out with ceremonial stages that are in accordance with the teachings of his religion and comply with local religious and customary norms in the form of provisions and restrictions (as a form of mutual tolerance in a traditional society). Religious norms, customs and traditional beliefs determine the rules of time starting from building and using dwelling space, which is marked by certain ceremonies at the beginning, the process of implementation and the end of a dwelling space construction (Putra 1997).

Each stage of the process in establishing dwelling space, as it begins with the manufacture of dwelling building foundations, making the wall until melaspas the buildings, each of which has dewasa ayu. The shape of the dwelling building is due to the demands of the life attitude that requires space to support the activities of the 
tradition in their life. The traditional attitude of life differentiates between human relations with God, human relations with others and human relations with nature (Tri Hita Karana) which is manifested in the differentiation of areas of parahyangan, pawongan and palemahan (Putra 1997). Differences in life attitudes also underlie the forms of dwelling space. Traditional life attitudes based on the philosophy of Tat Twam Asi applied in the relationship of humans with their dwelling space. The traditional Balinese dwelling space has a friendly attitude that accepts outside influences through a process of adjustment, so that the inclusion in its presence is harmonious as a whole.

The traditional conception can be seen in the environmental pattern, the shape of the dwelling space as well as the building elements. There are several basics that are conceptualized in traditional Balinese dwelling space, such as: a. Rwa Bhineda which are two different but inseparable things, b. Tri Hita Karana which is the three elements that make a life that is physical, energy and soul, c. The building forms are conceptualized in the Tri Angga as head-body-foot icons (each of which is a roof, a bearer construction and a weight-bearing construction on the ground below). The concept of Tri Angga are referred to as upstream-middle stream-downstream applied as the guidance in zoning with the value of utama-madya-nista as the value of the head, body and legs, d. Manik ring Cucupu, like a foetus in its mother's womb. This concept has the understanding that dwelling space and its environment have relationship that influence each other.

To achieve the aesthetic quality of a dwelling space, the undagi of the building not only rely on their intuition in making a decision, but refers to the guidance obtained through measurements of body parts such as palms, soles, arms, fingers and so on (Budihardjo, 1986). The measurements are obtained through comparisons based on the dimensions of the members of the human body (Remawa, 2015). According to Remawa's interview (2014), this gegulak was also made to meet the demands of Balinese people for the desired measurements in designing a traditional building, such as bale saka papat, bale saka kutus to bale saka roras. Architectural sizes and interior elements searched by using comparison of human body dimensions proportions (anthropocentric) and an added measure of pengurip to be able to "vitalize" or give soul (taksu) on the building. As mentioned by Reuter (Maharani 2017):

The house is at once a dwelling place for embodied human beings and an analogy of a body, for the body itself is regarded as the house of the soul (atma, urip). This analogy is made explicit in determining the proportion of house...derived directly from the bodily proportion of its initial owner.

\section{Analysis And Interpretation Of Sidatapa Village Dwelling Space}

Historically, Sidatapa village was originally named Gunung Sari village which consisted of three regions, namely in the East (Sengkurang), Southwest (Leked) and the middle which claimed to be followers of the Resi Markandeya. One time, two of the three regions, namely those in Sengkurang and Leked, experienced a disaster, while the middle area was safe and sound. Seeing the situation in the central region which is very safe and there are no disturbances, residents in the other two regions have the initiative to make an agreement with the people in the middle (white residents).

Then they agreed to carry out the tapa brata asking for God's guidance and grace. The place to carry out the tapa brata is now used as the Bale Agung Village Temple. This caused the settlement whose initial name was Gunung Sari to change its name to Gunung Sari Munggah Tapa. This event took place in Caka 785 and since then this settlement has no more disturbance. Due to the success of the tapa brata, Gunung Sari Munggah Tapa village has changed its name to Sidatapa village, which means successfully implementing tapa so that it can get what it wants (sida means successfully getting and tapa means carrying out tapa brata).

Sidatapa Village is located in a hilly mountainous area about $500 \mathrm{~m}$ above sea level, with a slope of about 25. This settlement is linear in pattern with dwelling yards scattered on the right and left side of the main road of the neighbourhood with a width of about $700 \mathrm{~cm}$, and has a slope of land that tends to be sloped. The settlement orientation is towards the mountain which is considered as luan or kaja direction (in the direction of the direction of the settlement). On luan part of the settlement contained Bale Agung Village Temple. 


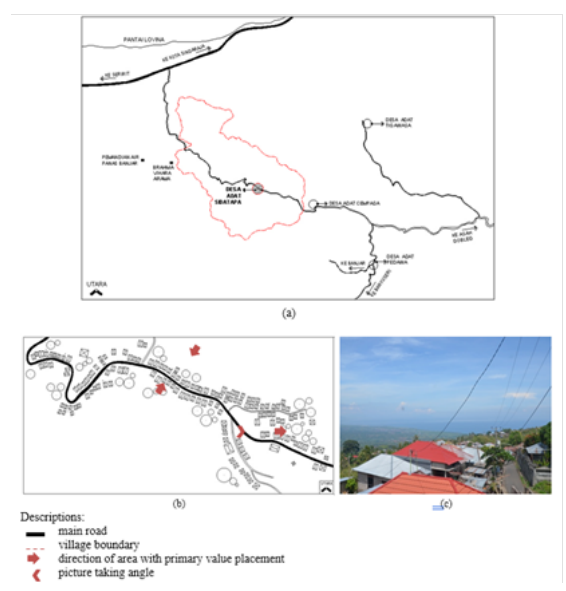

Figure 1. Sketch of the map and boundaries of Sidatapa village

(a), Sketch of Sidatapa village top view (b) (Author, 2018)

\subsection{Dwelling Yards Layout System}

Dwelling yard in Sidatapa village spread along the main street of the neighbourhood settlements, without any sign of ownership land borders of one family to another (do not have boundary penyengker wall) so it is difficult to determine the number of families who inhabit a dwelling yard. There is no land border with a neighbour, this mean ties of kinship, solidarity, tolerance and cooperation is still strong. The traditional house in Sidatapa Village is called bale gede saka roras tumpang talu. The shape of the dwelling building with pelinggih or paga ulu in the inner room, until now passed down from generation to generation until the grandchildren. Even for some new dwelling buildings that have followed the shape and use of modern materials, still maintain the existence of pelinggih, pepaga or paga ulu in the space in the back of the modern dwelling building (only visible after passing through the modern part of this building).

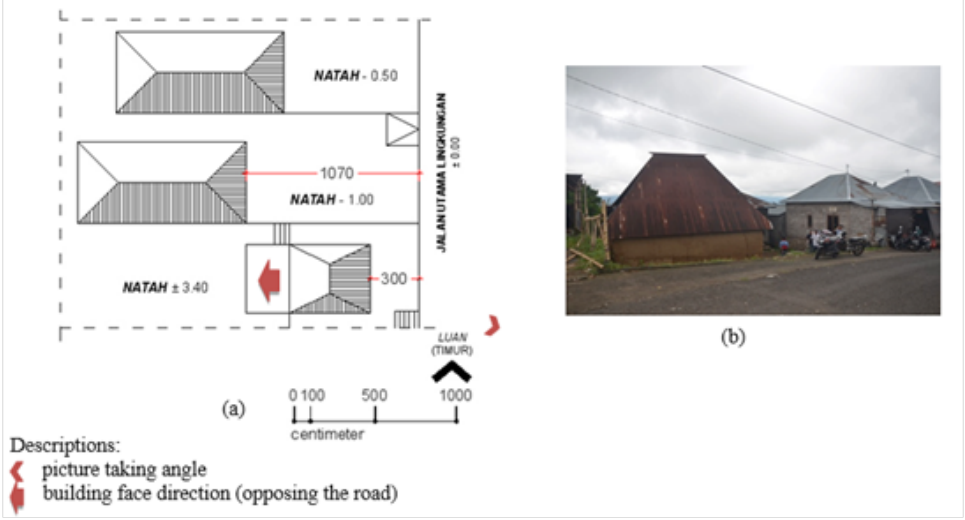

Figure 2. One of Sidatapa village dwelling yard layout

(a) and perspective photo from road angle (b) (Maharani, 2018)

\subsection{Dwelling Buildings: Bale gede saka roras tumpang talu}

The Sidatapa traditional house is called bale gede saka roras tumpang talu or telu, meaning a large house, saka roras means using 12 supporting pole, tumpang talu or telu means having three levels or rooms namely utama, madya and nista mandala. The utama part is a place for pelinggih sesehunan or panembahan placed on paga ulu, pelinggih Batari Sri (Hyang Kemongmong/Sri Tegteg/Sri Tumpuk). Due to pelinggih or paga ulu existence in the inner room of bale gede saka roras tumpang talu, then the material of roof covering used cannot be made from the soil (eg soil tile) that deems to contains impurities (according to the results of interviews with Nyoman 
Parma, 2018). Initially, for building materials used, always obtained from nature such as roof coverings from reeds leaf material, saka made of wood, walls or fence made of processed clay (for three days) or popolan soil. Bale gede saka roras tumpang talu forms resembles a mountain.

The worshipping place in the bale gede saka roras tumpang talu is in the form of pelangkiran in the south (kaja), God's stana placed on top of the bed, sanggah taksu placed under paga ulu and pelinggih Hyang Saraswati as a storage area for lontar and weapons which is placed in the north (kelod). There are two bale in this area, that aside from functioning as bed is also used for ceremonies place of Manusa yadnya such as pawiwahan, mesakapan, punjung (munjung), the sudang taluh (nelung bulanin) ceremony, ngerebas (enem bulanin) and mesayut (pawintenan) ceremony. The madya part of bale gede saka roras tumpang talu used as a place for daily activities in the form of cooking (kitchen) and as a place for pitra yadnya ceremonies such as mesagi, megat brata and others (in bale pepenggak). In this area there are also some pelinggih called pepaga punapi (located above the kitchen), pelinggih of Hyang Brahma, pepaga pelinggih of Hyang Wisnu and pepaga apit lawang. The nista part of bale gede saka roras tumpang talu in the form of an outdoor patio, is used as a place of daily activities such as making households works (maulatan) and place to receive guests.
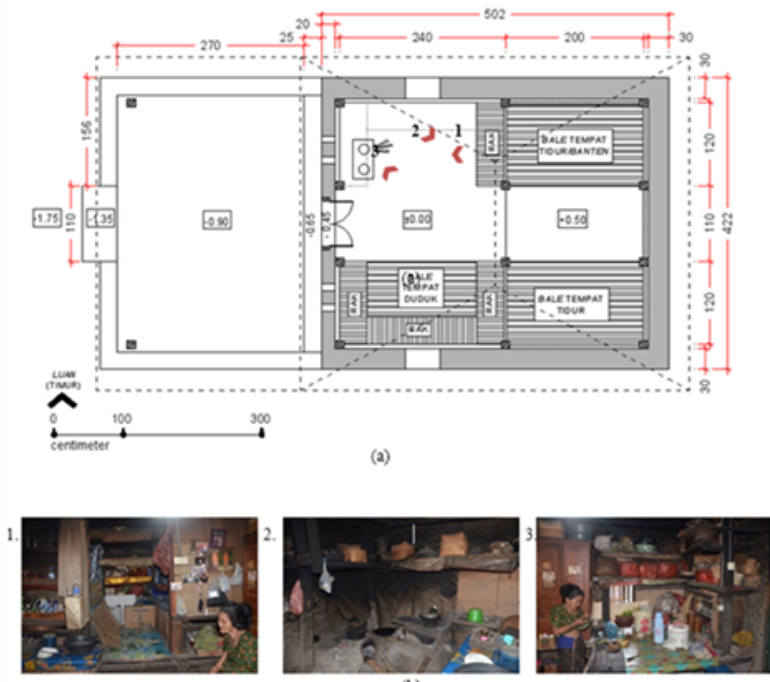

Descriptions:

(picture taking angle

Figure 3. Spatial arrangement in Raras's bale gede saka roras tumpang talu in Sidatapa Village

(a) and a spatial perspective photo in Raras's house showing the main room

(b1) and the middle area (b 2-3) (Author, 2018)

In the past, the traditional house of saka roras tumpang talu usually use traditional materials for roof coverings from the reeds. Its wall made of popolan clay, using the bacakan of wood such as jackfruit wood (prabu), teak (patih), tangi wood, kemit wood (punggawa) and ganggangan wood (prajurit). Jackfruit wood is usually placed on the ceiling and in paga ulu, tangi wood is placed on a bed, ganggangan wood is placed on the door and kemit wood is usually placed on the angkul angkul. The distance between the ceiling and the floor is about $200 \mathrm{~cm}$. The ceiling uses bamboo matting, to make it easier to remove smoke from the furnace burning. The floor of the building is still left in the form of soil, without using floor covering material. Openings of the building in the form of a door with a height of about $240 \mathrm{~cm}$ high and $66 \mathrm{~cm}$ wide. There are also two small holes for ventilation near the kitchen area (front façade), each with a height of $20 \mathrm{~cm}$ and a width of $10 \mathrm{~cm}$, and two small windows in the madya area (side façade) with a size of about $40 \times 40 \mathrm{~cm}$. 

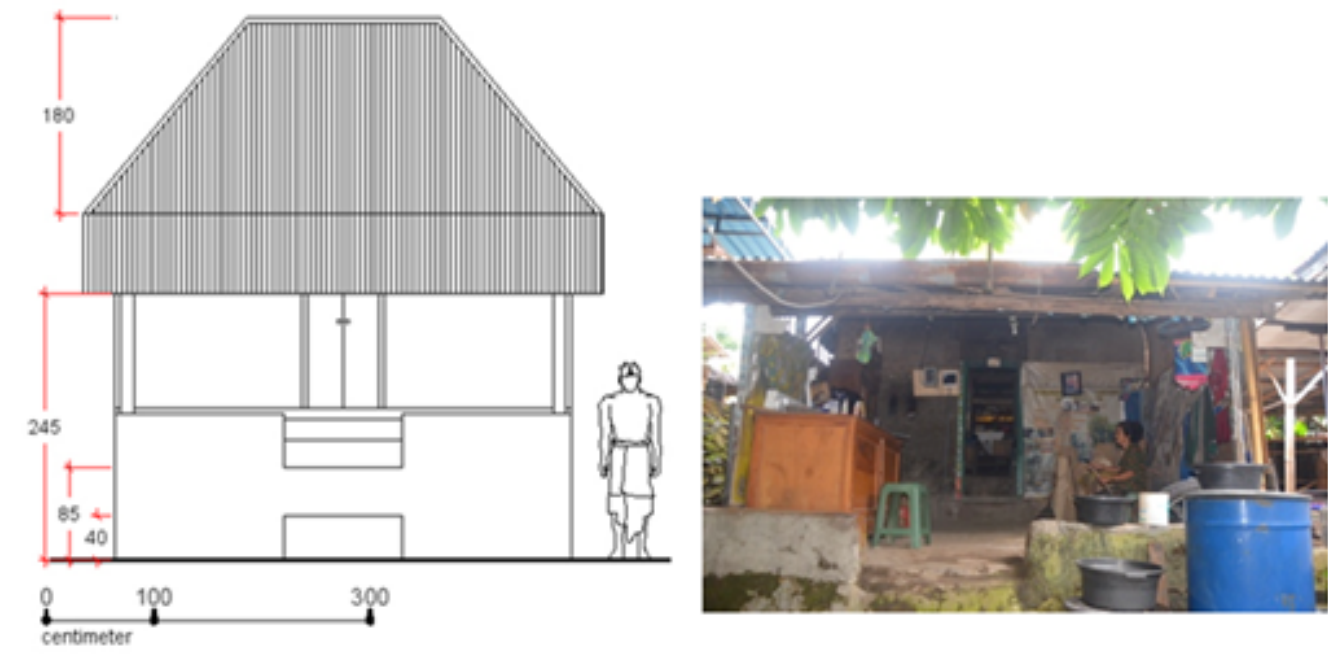

Figure 4. Raras' Bale gede saka roras tumpang talu

front view in Sidatapa village (Maharani, 2018)

The construction details of dwelling buildings in these settlements are similar to the previous Bali Aga settlements that used peg and hole system in the connection of the poles in the inner room. The building does not have a trampa because the burden of the building is passed on to the bearing walls of popolan soil. Ornaments on the dwelling building in the Sidatapa village is not found.

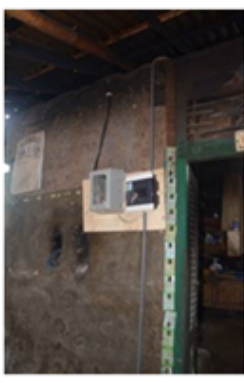

A

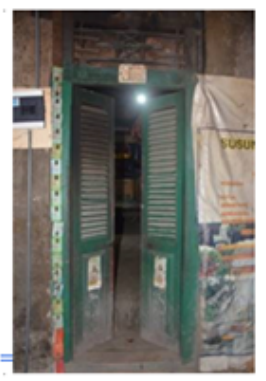

$\mathrm{B}$

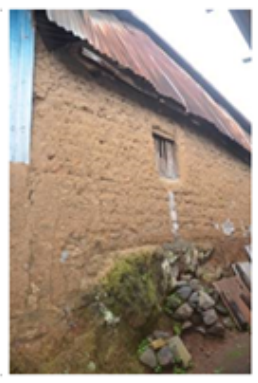

$\mathrm{C}$

Figure 5. Opening space in Raras' bale gede saka roras tumpang talu in Sidatapa village,

in the form of ventilation holes

(a), door holes (b) on front façade, and window holes in side façade (Maharani, 2018)

\subsection{Sidatapa village Dwelling Space that has Adapted}

Most of Sidatapa village dwelling buildings has changed. Some of the causes of these changes, is an effort of human adaptation to the environment, the arrival of the modernism effects and other influences.

a. Changes in Direction Course of the Dwelling Building.

Initially, the dwelling buildings in Sidatapa always had a direction opposing the road (see Figure 2), in accordance with the history of the village. But now with practical purposes most of the dwelling buildings, is now facing the main road to ease the access to the building. 


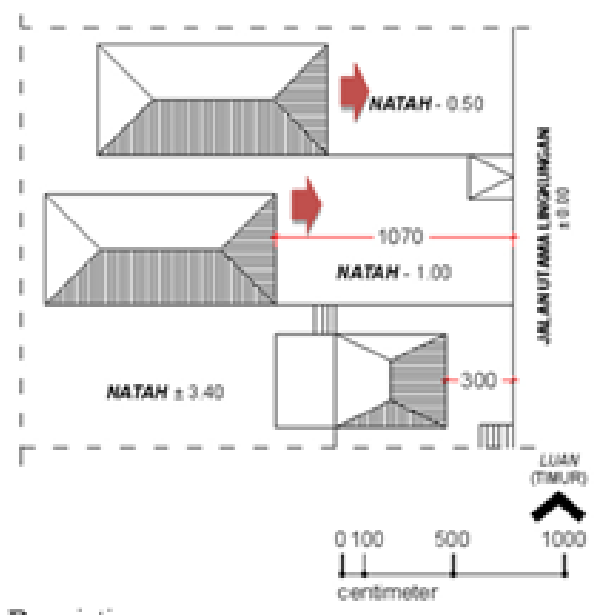

Descriptions:

Building direction course (opposing the road)

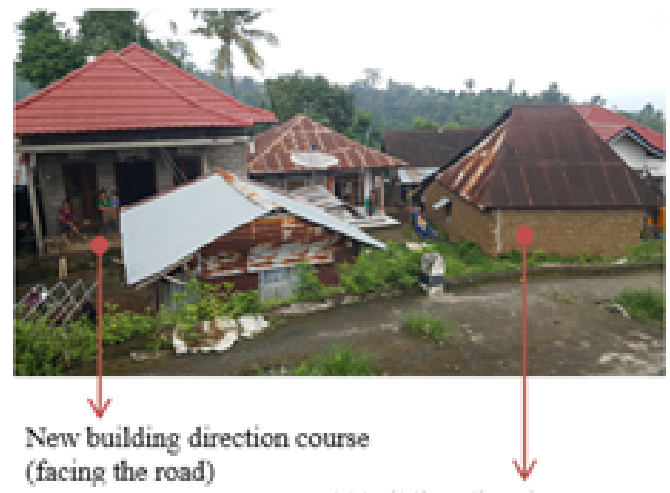

Old building direction course (opposing the road)

Figure 6. Changes in direction course of Sidatapa village dwelling building

b. Changes in Spatial Layout in Dwelling Buildings.

Comparison of spatial layout in ancient traditional houses and buildings that has adapted buildings is the reverse position of pelinggih in the inner space between ancient and modern buildings, but then it is not a big problem for the people of Sidatapa village. As a result of changes in the direction of dwelling buildings, the spatial layout of the buildings also changed. Initially, dwelling buildings consisted of three zones (see Figure 6).

From the outermost zone which is in the form of a terrace, then the middle zone which has begun to enter the building in the form of a place for activities, then the deepest zone is a place for worship but also as a room to sleep. Walls as a dividing partition are only found between the terrace zone and the living room. The change has now entered new functions in several new dwelling buildings, which are also still divided into three zones. As the outer zone is a terrace, the middle zone is a place of human activity and the innermost zone is a place of worship. Based on field observations, the zone used to worship is a spatial layout of old dwelling buildings that was reduced and adopted into it. Thus, the direction towards this prayer area also changes.
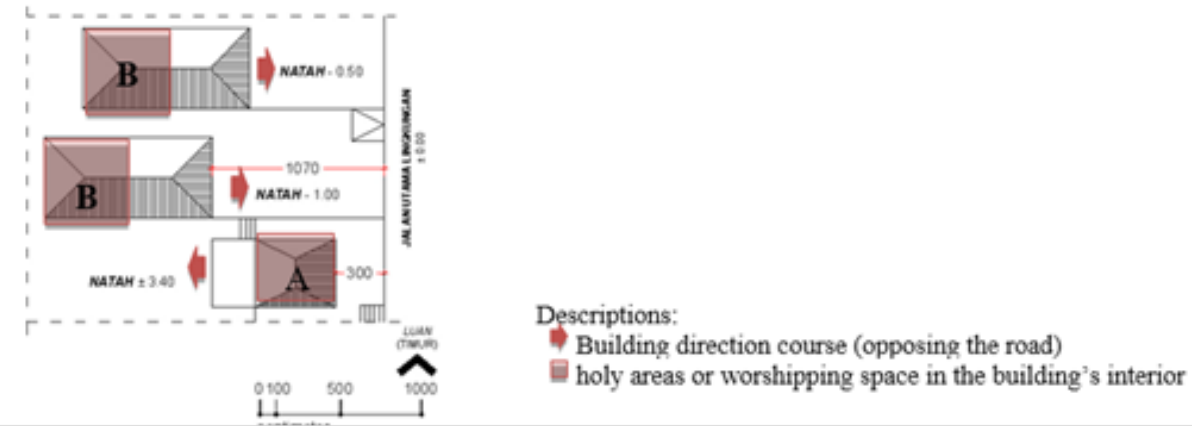

Picture 7. Pelinggih position in old buildings (A) and new (B) 


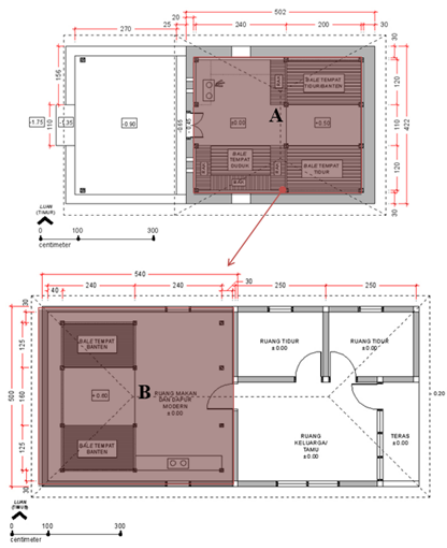

Figure 8. Spatial layout changes in old (A) and new (B) dwelling buildings

in Sidatapa Village (Author, 2018)

c. Changes In Building Materials Usage.

The change in the environment around Sidatapa Village resulted in the reduced use of material from the surrounding environment. On the floor of the old building that uses soil replaced with ceramic as a floor covering material, while in the sacred area or worship still use the original soil or hardening of concrete material. Popolan soil as wall material in the old buildings have been replaced by brick, the roof using wood shingles or bamboo changed with zinc plate. The customary system of the Sidatapa Village community forbids the use of soil as a roof covering, the traditional custom that the soil should be placed below as a place that is always trampled on. Thus, it would be inappropriate if the soil is installed on the part above the occupants, given that in the house there is a sacred area for prayer.

d. Material Changes cause the Dwelling Building Dimensions to Change

New dwelling buildings has been using measurements based on the size of the standardized fabrication material. The thickness of the building wall is adjusted to the width of the brick material, and it is no longer around $30 \mathrm{~cm}$ as thick as the wall of popolan soil. The dimensions of the complementary elements of the room, such as the door, no longer merely correspond to the height and width of the occupants' bodies, but have used standard door leaf sizes.

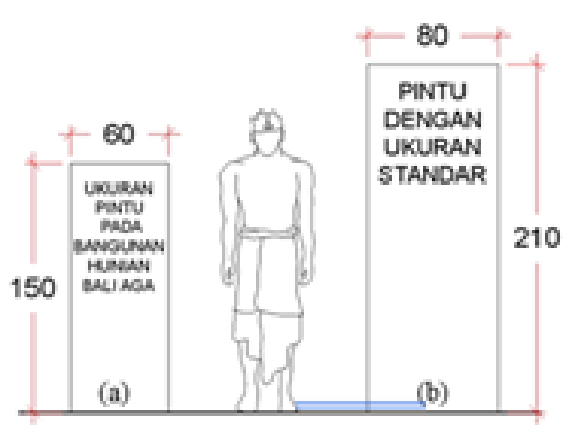

Figure 9. Comparison of door sizes in old (a)

and new (b) dwelling buildings (Author, 2018)

\section{Conclusion}

The background of the life of beliefs, culture, traditions and nature greatly influences the form of dwelling buildings in Sidatapa Village. For the people in the area, the dwelling building has symbolic meaning that is philosophical, because it is considered as a reflection of the cosmic world in a huge universe and the 
embodiment of a small universe. Pragmatically the dwelling building, is a container for forming and placing humans both individually and in groups, which must be in harmony with the universe as a whole. The attitude of harmony and unanimity starts from the traditional etiquette that must put something in its environment based on the principles of harmony and respect. Dwelling building is a picture of an understanding of the nature that is based on the analogy of the universe of small and translation principles of life that illustrates the totality of the tradition of community life as a whole.

At the beginning of dwelling buildings in the Sidatapa village is created in a response towards the surrounding environment (in tropical and humid conditions). Then gradually begin to include elements of belief and tradition in the concept of harmony, so that it has a strong character and personality. The form of dwelling building is made with simple technology and construction and building materials that have been available from natural surroundings, to overcome humidity roofing material that is very dominant in the building to see.

Eleven centuries later, dwelling buildings of the Bali Aga period are still reproduced by the community in the Sidatapa village, even though there has been a process of change in several parts and components of the building that were different from their original form. The results of observation and interviews in the field, shows that changes in dwelling buildings occur because of the process of adaptation to the values of functions, as well as the development progress of building materials that have high economic values. However, all the conveniences of building technology (building methodology, building materials), cannot shift people's obedience towards the beliefs and traditions. Because of that Sidatapa village community therefore do not 'deconstructed' the old dwelling building, but harmonize the dwelling buildings with the environment as the principle of harmony and respect. The division of the sacred area (mythic) and functional area (pragmatic) is still in the traditional order, as this dwelling building was first established in the 8th century. The existence of various influences as a result of changing times, responded to the concept of balance and harmony, this shows that the people of Sidatapa village have an indication to maintain the concept of the past that they want to implement in the present and the future.

\section{References}

Budihardjo, E. (1986), Architectural Conservation in Bali, Gajah Mada University Press, Yogyakarta.

Gartiwa, M. (2011), Morfologi Bangunan dalam Konteks Kebudayaan, Penerbit Muara Indah, Bandung 39-58.

I Nyoman Gelebet, dkk. (1985), Arsitektur Bali Daerah Bali, Jakarta: Departemen Pendidikan Dan Kebudayaan.

Maharani, I.A.D., Santosa, I., Wardono, P., Martokusumo, W. (2017), Faktor-Faktor Penentu dalam Sejarah Transformasi Perwujudan Bangunan Tinggal Bali Aga, Jurnal Kajian bali vol. 7 Okt. 2017, Universitas Udayana, Denpasar, 105 - 120 .

Oliver, P. (2003), Dwelling (The Vernacular House World Wide), Paidon, New York, 15, 84, 123, 174-175.

Putra, I Gst, Md. (1997), Pengetahuan Arsitektur Tradisional Bali, Program Studi Arsitektur Fakultas Teknik, Universitas Udayana Denpasar Putra.

Rapoport, A. (1969), House Form and Culture, Prentice Hall Inc, Englewood Cliffs NJ

Remawa, A.A. Gd. R., Raharja, I Gd M dan Cora, Tjk. I.R. (2006), Studi Village in Interior Rumah Tinggal Tradisional Bali Age (Bali Pegunungan), Penelitian Dosen Muda, Institut Seni Indonesia Denpasar.

Remawa, A.A. Gd. R. (2015), Konsep Estetika dan Ruang pada Gubahan Bangunan Hunian Bali Madya, Phd Thesis, Institut Teknologi Bandung.

Rudofsky, B. (1964), Architecture Without Architecture (A Short Introduction to Non-Pedigreed Architecture ), Museum of Modern Art, New York, 58.

Siregar, L.G. (2008), Makna Arsitektur (Suatu Refleksi Filosofis), Universitas Indonesia, Jakarta, 11-15.

Arai, T., Aiyama, Y., Sugi, M. \& Ota, J. (2001), "Holonic Assembly System with Plug and Produce", Computers in Industry 46, Elsevier, 289-299.

Bell, G.A., Cooper, M.A., Kennedy, M. \& Warwick, J. (2000), "The Development of the Holon Planning and Costing Framework for Higher Education Management”, Technical Report, SBU-CISM-11-00, South Bank University, 103 Borough Road, London, SE1 0AA.

Bongaerts, L. (1998), "Integration of Scheduling and Control in Holonic Manufacturing Systems", PhD Thesis, 
PMA Division, K.U.Leuven.

Deen, S.M. (1993), “Cooperation Issues in Holonic Manufacturing Systems”, Proceedings of DIISM'93 Conference, 410-412.

Techawiboonwong, A., Yenradeea, P. \& Das, S. (2006). A Master Scheduling Model with Skilled and Unskilled Temporary Workers", Production Economics 103, Elsevier, 798-809.

Valckenaers, P., Van Brussel, H., Bongaerts, L. \& Wyns, J. (1997), “Holonic Manufacturing Systems”, Integrated Computer Aided Engineering 4(3), 191-201.

Van Brussel, H., Wyns, J., Valckenaers, P., Bongaerts, L. \& Peters, P. (1998), "Reference Architecture for Holonic Manufacturing Systems: PROSA”, Computers in Industry 37(3), 255-274. 